\title{
The European Union and the United Arab Emirates as civilian and soft powers engaged in Sustainable Development \\ Goals
}

\author{
Adam Krzymowski \\ Department of International Studies, Zayed University, \\ United Arab Emirates \\ ak7@,p.pl \\ ORCID 0000-0001-9296-6387
}

\begin{abstract}
The article analyses the European Union (EU) - as European international organisation and the United Arab Emirates (UAE) - the only federal state in the Arab World as civilian and soft powers, strongly active to reach the UN 2030 Agenda. The ambitious projects, as well as actions, strategies, and visions of this international entity for reaching Sustainable Development Goals, should be analysed due to its impact on the international environment and emerging new international relations architecture. The author carried out research using primarily descriptive and analytical methods. To this end, rich source material, such as documents, strategies, and statements has been tested. In findings, the article presents the EU and the UAE as civilian and soft powers, its projects, and their implementation, including the green economy program, the energy strategies, and initiatives related to climate changes, humanitarian aid as well as in favour for peace, security, and tolerance. This research in conclusion demonstrates the role and significance of Sustainable Development Goals for the European Union as well as the United Arab Emirates strengthening power in the international arena.
\end{abstract}

Keywords: Sustainable Development Goals, European Union, United Arab Emirates, renewable energy, climate changes.

JEL Classification: D74, F02, H56, O33, O34

\section{INTRODUCTION}

The European Union (EU), as well as the United Arab Emirates (UAE), are unique entities of international relations as soft and civilian powers. The problem of the study is Sustainable Development Goals which on the one hand, as one of the most important tasks of the global agenda, and on the other the world's most important tools for soft and civilian power. The European Union is the most integrated regional international organisation with a great impact on the UN 2030 Agenda. The United Arab Emirates 
is the only federal state in the Arab World with a huge ambition to become number one in the world in achieving Sustainable Development Goals. Moreover, the UAE have adopted and realise many strategies, policies, as well as projects in this journey. The United Arab Emirates due to immigration, is one of the fastest countries in the world in an increasing number of habitats, especially in cities, like Dubai, Abu Dhabi. Therefore, the UAE authorities have taken decisions to build sustainable cities. The foundation of strategy 'Abu Dhabi Vision 2030' is Estefana program (in Arabic: 'sustainable development'). The project imposes the highest ecological standards and a balanced approach to the design, construction, and management of buildings and communities. This is one of the first such initiatives in the Middle East (Krishnadas, 2016). Moreover, Dubai is implementing many strategies related to sustainable cities. Additionally, Dubai is the organiser of Expo2020 which is an important element for the United Arab Emirates' soft power as the ability to influence others through networks along with the ability to persuade according to our goals (Nye, 2004). In that mega-event, a strategic project to the UAE, one of the most important themes is sustainability. Additionally, each Emirate build owns an ambitious sustainable programme. The United Arab Emirates is undergoing a transition from an economy based on oil extraction to an eco-economy based on new technologies, including those related to renewable energy sources. From a global perspective, in reaching the UN 2030 Agenda, as Clark (2018) underlines, the international community should create an effective multilevel and multidimensional network of global strong cooperation. The presented research paper indicates that the European Union and the United Arab Emirates should be very important parts of this global platform. Therefore, the UN 2030 Agenda, Sustainable Development Goals are a great opportunity to establish new relationships and enhance cooperation as well as strengthening the nation's brand (Saberi et al., 2018). Moreover, for both, the United Arab Emirates and the European Union as soft and civilian powers, reaching of Sustainable Development Goals is an excellent occasion to co-shape the new global architecture of international relations. However, the UAE needs to increase the number of impact instruments as well as their effectiveness in the implementation of the Soft Power Strategy and United Arab Emirates Centennial 2071 Agenda. While the European Union needs to expand influence in the Arab World.

\section{LITERATURE REVIEW AND METHODOLOGY}

The research paper analyses the global program associated with the most important challenges for our planet with a particular focus on the European Union as a global leader and the United Arab Emirates, a leader in the Middle East and North Africa (MENA) region in achieving Sustainable Development Goals. Therefore, the broadcasting problem presented in this analysis, it is current and very important for many reasons, including for building the international position of both entities. The goal of this analysis is to demonstrate research on the role and significance of the European Union and the United Arab Emirates for UN 2030 Agenda, Sustainable Development Goals. This research paper makes a concrete contribution to the development of knowledge about international relations in the context of SDGs implementation. This analysis gives the answers to the research question, what are the achievements of the UAE and the European Union to fulfil UN 2030 Agenda and how both international entities with different international roles and positions can cooperate. The research demonstrates different international entities with their interests, world ambitions in the context of reaching common goals, facing global challenges and building new international order with interdependence. Moreover, the research approach has a practical aspect because it is analysed by an author who has participated in many initiatives and diplomatic actions in the research field. Although there are many publications regarding civilian power, soft power, however connecting unique, and the most integrated international organisation with unique a federal state in the Middle East in the context of the UN 2030 Agenda, as well as new emerging architecture of international relations, expands knowledge about this problem. This research paper is the author's contribution to the 
international debate on challenges in new international conditions in an interconnected world, and at the same time in the period of seeking answers to the new global order.

The author carried out scientific research using primarily the descriptive and analytical method. To this end, rich source material, such as documents, strategies, and statements has been tested. Besides, the theoretical framework of scientific research was adopted, among others, neoliberal theories of international relations, asymmetrical concepts, complex interdependence, and complex transnational connections. The theory of constructivism and neo-institutionalism were also used. In addition to analysing the source materials, the extensive literature on civilian power and soft power has been taken into account. One could not miss the scientific achievements in this area of François Duchêne, Joseph Nye and Robert Keohane. The analyses of the critical approach to the EU as a civilian power Karen Smith, or with a different of Christopher Hill analysis were also valuable. The texts of Jan Zielonka deserving special attention, emphasizing the strategic EU choice. Regarding the research of the UAE with the ambition to obtain a global position of super soft power, in addition to source materials, valuable were the analyses of the Mohammed Bin Rashid School of Government in Dubai, the Emirates Diplomatic Academy in Abu Dhabi, and the UAE National Defence College. Also, studies by Ahmed M.J. Al Suwaidi, Steffen Hertog's study, from the London School of Economics and Political Science, or Eleonora Ardemagni, from the Italian Institute for International Political Studies (ISPI) were interesting. Moreover, the author's direct participation in many initiatives and projects of the studied area helped to deeply analyse the available information.

\section{THE PROBLEM OF THE STUDY}

\subsection{The European Union as a civilian power}

The concept of civilian power appeared in the early 70s, proposed by Duchêne (Duchêne, 1972). In the first definition of civilian power, François Duchêne draws attention to two of its elements, namely means and goals. At the same time, he believed that the European Communities / European Union should be a model of a new stage in political civilization that will build an international community based on the recognition of common values, challenges, and responsibilities, including for the global environment, equality, justice as well as tolerance (Duchêne, 1973). Whereas, J. Nye in the 80s proposed the concept of hard power and soft power, which was defined as achieving goals thanks to the attractiveness of our country and its policy through acceptance of the values we promote, the attractiveness of our culture and leadership in the areas of knowledge and technology (Hill, 1990). Civilian power, in which the entity, using economic, financial and political means, shapes the international environment and its system. Moreover, a civilian power undertakes extensive diplomatic activities in solving global challenges. To this end, civilian power uses multilateral structures and mechanisms, including international organizations (Manners, 2002). According to Maull, a civilian power requires, while pursuing our own goals, it is necessary to cooperate with others, using primarily economic means, and to contribute to strengthening transnational cooperation structures to meet the challenges of international management. However, it should be added that, according to Maull, the military element is not completely abandoned, but remains as part of another type of international cooperation (Maull, 1990).

After the establishment of the European Union under the Maastricht Treaty (1992), civilian power has become a clear strategic choice (Riddervold, 2016). However, the armed conflict in the Balkans has made the Member States aware of the need to also have military instruments of influence. Therefore, the next treaty (Amsterdam, 1997) adopted a provision enabling the EU to be active in humanitarian missions, peacekeeping, and crisis management. Besides, it was appointed the representative of the Union for the 
Common Foreign and Security Policy (Lonardo, 2017). When assessing the European Union's international role, we should, first of all, perceive its position as civilian power in the context of its policies regarding enlargement, external assistance, peacekeeping, and multilateralism (Brljavac \& Conrad, 2011). Romano Prodi, the President of the European Commission in 2000 at the beginning of his post, he underlined that the European Union should be a global civil power (Prodi, 2000). The next impulse for the development of the military component was the events of September 11, 2001 (Gnesotto, 2001). Changes in international relations in connection with new challenges after the end of the Cold War and the events of September 11 have brought changes in the understanding of civilian power (Pehlivantürk \& Demirtaş, 2018). The EU should also have military resources as a complement to other civilian power resources and to be ready to respond to international crises, especially in the event of serious human rights violations. Javier Solana, the EU's High Representative for the Common Foreign and Security Policy, on 19 February 2002 explicitly emphasized that if the EU wants to be effective civilian power it must have military instruments as a component of it (Burckhardt, 2004).

In this research, the author would like to attract attention for the next event, which on the one hand divided the EU and other hand accelerated work on granting the next military instruments to the European Union, was the US military intervention in Iraq, in March 2003. Therefore, in December this year, the EU adopted a security strategy that emphasizes the EU must be not only civilian power but also global power. Then, in 2004, the Member States adopted the project of the European Constitution which planned an ambitious role and importance of the EU in international relations. However, in France and the Netherlands, in referendums, the draft Constitution was rejected (Riddervold \& Rosén, 2016). Therefore, further negotiations were undertaken to develop a new treaty text, which entered into force on December 1, 2009 (signed in Lisbon on December 13, 2007). The new treaty is a compromise that meant that its provisions were no longer as ambitious as the draft constitutional treaty (Koutrakos, 2017). However, the new treaty also brought some positive impulses. One of them is to give the EU international legal personality, which has made the European Union an international organization and a full formal global actor (Laursen, 2016). From that moment, the European Union could sign international agreements and treaties not as Communities, but as a unified international entity. Also, the treaty referred to the fundamental universal values of the EU, which aims to promote peace, values and the well-being of its people (Lequesne, 2016). Besides, the Treaty through the new instruments has given the European Union a greater range of possibilities to strengthen civilian power. Also, the EU has wanted to be active in persuading other international entities to cooperate closer to global economic or environmental challenges (Erdağ, 2016). Smith emphasizes that the EU is no longer a civil power, and its position in international relations is between ideal soft and hard power models. The EU, like many international entities today, has dilemmas which way to go. Smith is opposed to combining military means with elements of civilian power (Smith, 2005). Analysing the processes taking place in the EU and referring to scientific discussion and theories, I think that the European Union remains civilian power. However, it must be supported by the Common Foreign and Security Policy being developed. Thus, the EU as a global civilian power must have at its disposal a full range of international influence, increasingly seeking smart power.

Additionally, this research demonstrates that the European Union gives the emerging new world order a pattern of governance that we can call 'multi-regionalism'. In the dimension of processes taking place in the era of globalization and the $4^{\text {th }}$ industrial revolution, the $\mathrm{EU}$ as a civilian power takes on an even more important role and significance. According to Hettne, Söderbaum (2005) if the EU becomes more 'speaking with one voice' and its values are more universal, its impact on global governance and shaping the new world order will increase even more. Jan Zielonka (2006) believes that Europe as a civilian power is a fundamental strategic choice that should help strengthen the EU's identity and legitimacy, as well as play an important role in international relations. I want to underline that the EU with its foreign policy and 
diplomacy is a unique international entity that, despite various expectations, will be active in the external dimension, bringing new initiatives and a model of global management as civilized power to the international community. The EU will expand its commitment to the environment, climate change, health, human rights protection, financial stability and other transnational challenges (Telò \& Ponjaert, 2016). However, events in international relations verify theories and assumptions. The wars in countries of the EU's special program, the Eastern Partnership, in Georgia in 2008 and, started in 2014 in Ukraine, indicate the need for the EU to have an effective military element for civilian power. Thus, the European Union should shape the global structure of international relations and their entities, based on the values of solidarity and sustainable development (Özer, 2012). Everts (2002) believes that civilian means of power should deliver more sustainable solutions. An EU with the power of attraction and persuasion to define bilateral partnerships, based only on civil resources (Tulmets, 2008). Referring to the numerous discussions on the development of European integration, including the role and significance of the EU in the international arena, and many interpretations of the EU as a civilian power, it should be emphasized that this research paper proves that this organization maintains this position. Currently, after Brexit, the full commencement of the new composition of the European Parliament, the European Commission and the new President of the European Council, as well as negotiations on the new EU financial perspective, can largely give this organisation the opportunity to clarify the role of the European Union in the world as the importance of the EU, as a civilian power. Therefore, to increase its capacity to create a new architecture for global management of strategic challenges, the EU needs a deepened strategic cooperation with the United Arab Emirates, especially on SDGs.

\subsection{The United Arab Emirates as a soft power}

The United Arab Emirates is a unique country that deserves special analysis. The UAE were founded in 1971, as the only state in the Arab World with a federal structure. Although it is a small country in terms of size, it is strategically located near the Strait of Hormuz, through which nearly $40 \%$ of the world's oil and gas flows. The leader of the unity of the Emirates, HH Sheikh Zayed Bin Sultan Al Nahyan, the ruler of the Emirate of Abu Dhabi and the first president of the country laid its foundations. One of them is tolerance, openness, implementation of foreign policy and national interests founding on peace and negotiations (Abed \& Hellyer, 2001). Also, HH Sheikh Zayed started promoting the brand of the country, which began to attract many people and projects from around the world as well as created a unique model of the country with quickly increasing its role and significance as a positive added value for international relations (Stephens, El-Sholkamy, Moonesar \& Awamleh, ed., 2019). So, from the very beginning of the establishment of the UAE, their policy was based on the assumptions of soft power, before this concept began to function for the first time, by the University of Harvard professor, Joseph Nye. Besides, the founder of this country also quickly recognized the importance of environmental protection. Although the wealth of the state was based on profits from the sale of oil, the United Arab Emirates began the economic diversification program almost immediately from the beginning, investing rapidly in education, infrastructure, and new technologies. At the same time, Dubai has gained an important international position in trade and financial services. Dubai has also become a global brand in itself. However, the Emirate of Sharjah has become a recognizable place of science and culture. Since 1982, Sharjah is a pioneer in the Gulf as an organiser of the International Book Fair (Ardemagni, 2019). To build the strong position of the United Arab Emirates in the world as soft power, attracting many international partners, including the financial and tourism sectors, the UAE authorities decided to establish influential Sovereign Wealth Funds (SWFI, 2019) and develop the appropriate infrastructure. Considering the total assets, the Abu Dhabi Investment Authority ranks $3^{\text {rd }}$, while the Investment Corporation of Dubai is $12^{\text {th }}$ in the world. The state has one of 
the largest seaport's containers and airports, constantly expanding its possibilities. Dubai has one of the world's largest airlines - Emirates Airlines, which also play a unique role in national brand and soft power. Emirates is recognized as a global sponsor of many world sports events and clubs, among others football clubs like Real Madrid and AC Milan, Arsenal London, Benfica Lisbon, Hamburger SV.

Analysing the challenges and initiatives of the UAE in recent years which are strengthening soft power, I would like to mention the establishment in December 2012 by the Minister of Foreign Affairs and International Cooperation $\mathrm{HH}$ Sheikh Abdullah bin Zayed Al Nahyan the International Centre for Excellence. Based in Abu Dhabi, this organization, commonly known as 'Hedayah' (in Arabic means guidance), is an international collaboration platform as Counter Violent Extremism (CVE). In July 2015, the UAE together with the USA established the Centre 'Sawab' (In Arabic means the right path). This initiative aims to build global instruments on the internet to fight extremism and terrorism (Government.ae, 2019). In 2016, the UAE authorities have established the new position of the Minister of State for Tolerance, which was then taken over by Sheikha Lubna Al Qasimi. Additionally, in June this year, the National Tolerance Program was initiated. Then, in April 2017, the UAE Soft Power Council have started its activities. Vice President, Prime Minister and Ruler of Dubai, His Highness Sheikh Mohammed bin Rashid Al Maktoum appointed the Minister of Cabinet Affairs and the Future, Mohammed Abdullah Al Gergawi as head of this initiative (WAM, 2017). The task of UAE Soft Power Council is to coordinate activities related to the implementation of the United Arab Emirates soft power strategy, which was announced publicly in September 2017 at an international conference Government Summit (Woodward, 2018). UAE soft power strategy sets four main goals. The first task is to coordinate many areas of the state's functioning, including the economy, humanities, media, science, and tourism. The second task is to strengthen the position of the UAE as a gateway to the region. The third goal is emphasising the need to strengthen the United Arab Emirates as the regional capital for culture, art, and tourism. The fourth objective focuses on building a modern and tolerant country. All strategy goals are to be implemented based primarily on diplomatic activities, including humanitarian, scientific and academic diplomacy, as well as cultural and economic diplomacy (MOCAF, 2017). As Günek (2018) underlines, all soft power goals rely on the country's global reputation, the state's brand. A member of the Soft Power Council and Director-General of the Public Diplomacy Office at the Ministry of Cabinet Affairs and the Future, Saeed Mohammad Al Eter said that implementation of soft power strategy will have an impact on increasing UAE' role and significance for emerging new architecture of international relations (Gulf News, 2017). The United Arab Emirates wants to become a global leader in innovations for the renewable energy field (Hertog, 2017). In recent years, a large number of universities, both local and foreign - world top, have emerged. They play an important role in the implementation of soft power strategy and country development. In 2019, the year of the tolerance in UAE, 3-5 February took place, a unique, historic visit of His Holiness Pope Francis. The head of the Catholic Church, the spiritual leader of a significant part of the world, came to the Arabian Peninsula, the birthplace of Islam for the first time. About 150,000 people attended the mass at Zayed Sports City in Abu Dhabi. This event was of exceptional importance for the UAE national brand and soft power. Moreover, Sharjah in 2019 is the World Book Capital. At the same time, strengthening the country's brand, in 2019 (September 25 - October 3) UAE for the first time sent the Arab astronaut Hazza Al Mansoori into space at the International Space Station (ISS). In cooperation with, among others, the European Space Agency, during this mission Al Mansoori conducted much scientific research. Moreover, the UAE has the first in the Arab region integrated Astronaut Program, whose goal is to participate in global research on the major challenges facing our planet and prepare people to participate in space missions. 2021 will deliver the next opportunity. In October 2021 - March 2022 Dubai will organise the World's Fair with the main theme Connecting Minds, Creating the Future in searching solutions for current and future challenges. One of the three subthemes is sustainability which is directly connected to UN 2030, Sustainable 
Development Goals. At the same time, the UAE' an unmanned probe to Mars, as the first mission from the Arab world will reached this planet (UAE Space Agency, 2019). In 2021 we will celebrate UAE's 50 th anniversary and opening a new stage of development of the country, as well as expanding the national brand and global influence as soft power.

After conducting a research in the subject and my own experience of participation in many projects, the author would like to emphasize that, especially in this case, building a strong position with growing international roles require international interdependence. National interests are more effectively implemented in interdependence. Therefore, especially for a young, territorially small country, but with huge international ambitions, the implementation of this strategy requires larger, deep strategic relationships and interdependencies with the most integrated, based on interdependencies of international organizations in the world. Especially when it comes to global challenges.

\subsection{Sustainable Development Goals as a strategic priority}

The Sustainable Development Goals (SDGs) are priorities for the European Union, giving the EU a unique opportunity to increase its role as a civilian power. From this perspective, the European Union's example and its impact on many international actors in setting standards and initiatives should be highlighted. The EU, having the world's largest single market, being the largest investor and the largest donor of development and humanitarian aid, occupies a special position on the international stage in implementing the SDG (Reflection Paper, 2019). In 2010, the European Union adopted the Europe 2020 strategy: A European strategy for smart, sustainable and inclusive growth, which emphasizes knowledge and innovation, promoting the green economy (Europe 2020, 2010). By adopting an EU sustainable development strategy, EU institutions express will comprehensively realise sustainable development goals (Mulholland, 2017). The European Union had a huge impact on the shaping of the UN 2030 Agenda and Sustainable Development Goals. Therefore, the European Union is a global leader in implementing SDGs assumptions, which - as the European Commission emphasizes in its communication of November 29, 2016 - are priority elements of all European Union policies and initiatives. In the implementation of UN 2030, all European Union instruments are involved, both internally and externally. EU financial instruments have also been involved to make them effective. The best result is achieved in implementing SDG 1 (end poverty in all its forms everywhere). Then, in fulfilling the assumptions of SDG 3 (Ensuring healthy lives and promote well-being for all at all ages). However, analysing the global result, it should be noted that in the Global SDG Index, seven EU Member States are in the top ten, and all European Union Member States are in the top 50 out of 156 (Sustainable Development Report, 2019).

The United Arab Emirates at the same time, in 2010 published UAE Vision 2021. The strategy in a similar way underlines 'a diversified and knowledge-based economy' with a focus on several key areas, i.e. education, health, economy, police and security, housing, and government infrastructure and services. Later, the strategy has become an important step to face 3, 7, 8, 9, 16 SDG'. The Vision 2021 strategy shows the will of the UAE to move away from oil as the main source of income. The United Arab Emirates in January 2012 initiated the 'green economy for sustainable development' program. The main task of this strategy is to achieve sustainable development of the country by co-creating a new global model of the green economy. The United Arab Emirates have the ambition of becoming a global leader setting new trends, programs, international standards as well as a producer of innovative green technologies. Another goal of the program is to create environmentally and people friendly urban buildings. The next task set by the strategy are initiatives taken to stop the climate change process. Another goal of the 'green economy' are activities aimed at the sustainable use of natural resources such as water and electricity. Also, the program emphasises the need to take appropriate measures to recycle waste (Government.ae, 2018). In the context of Sustainable 
Development Goals related to water, it should be emphasized that in 2013 the EU adopted Strategy on Adaptation to Climate Change. For the European Union, sustainable water management is a fundamental challenge to climate change, both internally and externally, with a partner like the UAE (Water in the 2030 Agenda, 2019). To face goal 13, related to climate change, in May 2014, to combat the effects of climate change, the UAE has adopted a program to diversify its economy, and invest in renewable energy. As part of its international involvement in these areas, the UAE organised Abu Dhabi Ascent, attracting representatives of governments, scientific institutions and NGOs from around the world. (Alam \& Luomi, 2018). The implementation of national goals through diplomatic means, as soft power, will strengthen international position (Mills, 2017) and contribute to energy transformation (Griffiths, 2018) as well as deepen strategic relations, including with the European Union.

The United Arab Emirates in October 2014 have announced the National Innovation Strategy with the leading goal to become in 2021 one of the most innovative states. This initiative is based on seven fields of activities. The first area of this strategy underlines conducting research on renewable and clean energy and implementing it in the economy. The second sector is to find innovative solutions for transport and infrastructure. The third and fourth strategic goals are reaching the leading global position in technology, and education. The fifth sector is health with the best medical practice and services, as well as research with a focus on biotechnology. The sixth strategic goal is to find new technology in obtaining fresh water. The seventh is space. In this area, priorities are to obtain innovative technology for exploration and satellite communications and creating space industry (UAECabintet, 2019). To achieve the objectives of the first, second and third areas of the National Innovation Strategy, the Dubai authorities, in the same year, initiated the Smart City strategy, which emphasizes sustainable energy consumption, intelligent transport, and investment in recreational areas. In this context, attention should also be paid to projects in Dubai such as Sustainable City, where solar energy is produced locally, there are ecological farms, or Desert Rose City, where renewable energy is to be produced and waste recycling on-site (the State of Report, 2014). Dubai can be a global leader in implementing smart city projects whose global market can be estimated at around USD 1.5 billion by 2020. In addition, creating smart cities that have the entire multi-level and multi-faceted ecosystem (Al Hawi, Al Ketbi, Al Humairi, Thomas \& Warner, 2018) will have far-reaching strategic consequences not only in the dimension of the 4th industry revolution and digital transformation, but with serious consequences for socio-cultural changes (Salem, 216).

Dubai authorities in January 2015 launched the Dubai 2030 integrated energy strategy. The strategy assumes a gradual increase in renewable energy, by 2020 it will have a share of $7 \%$ of energy sources, and in 2030 already 15\%. Also, Dubai has a long-term, 2050 program to develop innovative energy technologies. It is the only initiative of this kind in the region, it provides activities in five areas such as improving energy infrastructure, adopting new legislation and budgets for implementing new technologies, as well as activities to increase the diversification of energy sources. In implementing the first strategic goal, in Dubai is the world's largest solar park, which is expected to reach full operational capacity in 2030 (Alevizos, 2017). According to the Clean Energy Strategy Dubai 2050, 75\% of energy in 2050 will be from clean sources. Besides, the implementation of this strategy is to ensure Dubai's position as a global leader in the use of clean, renewable energy while being a city that will have the lowest carbon footprint in the world (Urpelainen, 2018). Moreover, the strategic interest of the United Arab Emirates is to diversify the economy based on clean energy and to secure a global position as a supplier of energy sources, including renewable ones (Luomi, 2018).

To implement the development of a sustainable and diversified economy, the United Arab Emirates introduced many organizational changes, establishing new institutions as well as adopting new strategies. One of the initiatives is the National Strategy for Green Growth (NGGS), which was adopted by the government in 2015. NGGS has become a fundamental strategy to implement the Sustainable Development 
Goals, also giving Vision 2021 additional dimension and significance (Government.ae Climate action, 23 Dec 2018). In 2016, to implement projects on combating the effects of climate change and to increase scientific research for the benefit of SDG, as well as to develop close cooperation with the private sector, the UAE established the Council on Climate Change and the Environment (Ministry of Climate Change and Environment, 2019).
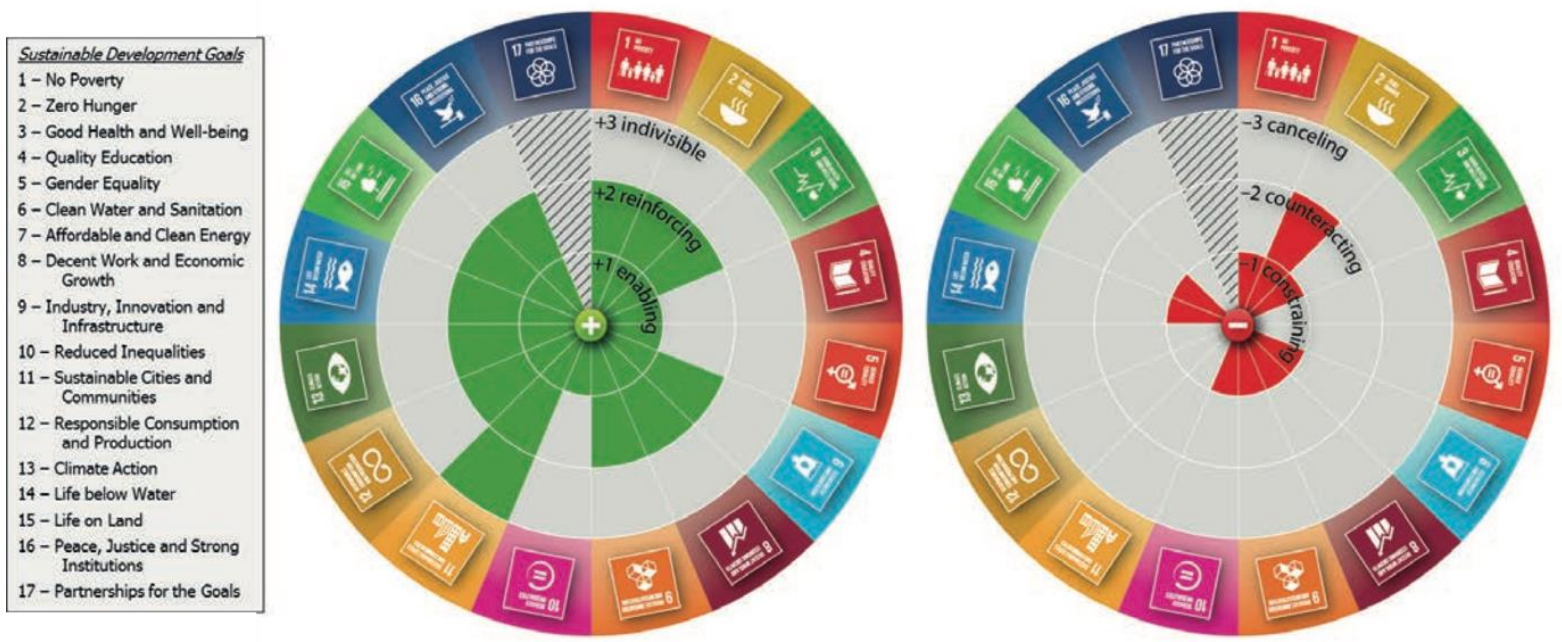

Figure 1. Sustainable Development Goals

Source: http://www.iiasa.ac.at/web/home/research/twi/TWI2050_Report_web-small-071018.pdf

In 2016, the Ministry of International Cooperation and Development of the UAE, which then became part of the Ministry of Foreign Affairs, and Dubai Carbon Centre of Excellence signed an agreement on close cooperation in implementing the Sustainable Development Goals. Another Dubai program is the 'Intelligent Autonomous Mobility Strategy' according to which 25\% of vehicles by 2030 should be without drivers. Besides, the strategy involves establishing a 'flying taxi' system (Smith 2017, cited in Burton, 2017). As a soft power engaged in sustainable development, on 27-30 March 2017, the United Arab Emirates organised the first Global Manufacturing and Industrialisation Summit (GMIS) at the Paris Sorbonne University in Abu Dhabi. During this event, the UAE as well as the European Union presented new solutions and technologies for changes in the manufacturing sector for the implementation of UN 2030, as well as building partnerships to successfully achieve Sustainable Development Goals. Building new platforms for cooperation to achieve global goals is key due to not only the new common global challenges, Fourth Industrial Revolution, but also due to the current process of searching for a new global structure of international relations. The GMIS initiative was established by the United Arab Emirates and the United Nations Industrial Development Organizations (UNIDO) in 2015. GMIS is the world's first global initiative to combine the efforts of governments, international organizations, NGOs, scientists, industry and the world of business for global sustainable development during the fourth industrial revolution. So it fits into the implementation of complex interdependence, especially using multiple channels of cooperation.

The European Commission in 2017, established The High-Level Multi-Stakeholder Platform on the SDGs, involving many international entities, showed the need for very close cooperation between the European Union and its partners from around the world. Also, this form of cooperation is an effective platform for the exchange of information on the progress of individual countries in the area of SDGs, as 
well as the impact on the UN forum (Reflection Paper, 2019). In the same year, 2017, the United Arab Emirates, to speed up and coordinate the implementation of UN 2030, appointed the National Committee for Sustainable Development Goals, which included representatives of government institutions with the Minister of State for International Cooperation Reem Al Hashimy as the chairwoman. Besides, as a part of the idea of a private-public partnership, the UAE authorities established a Private Sector Council for Sustainable Development Goals (Lootah, 2019). In 2017, the United Arab Emirates authorities adopted the 'Energy Strategy 2050', which is the first single strategy in the energy sector. The document assumes an increase from $25 \%$ to $50 \%$ to 2050 the share of clean energy. Moreover, the strategy sets a country-wide goal to reduce the carbon footprint of energy production by 70\% (Governmentae, 2019). In 2018 the European Commission, led by Juncker, presented a long-term strategic vision for the EU's 2050 environmentally friendly and outgoing SDGs economy. While the updated EU Bioeconomy Strategy presented in 2018 is a contribution to the development of an economy based on the sustainable use of renewable resources. The document proposed actions aimed at investments for the production, among others, fuels, chemicals, furniture and fertilizers (Reflection Paper, 2019). The next UAE's initiative to build an innovative society that can meet future challenges is the Advisory Council of the United Arab Emirates on Sustainable Development Goals, consisting of the young generation (Lootah, 2019). Therefore, the research shows that EEAC (Network of European Environmental and Sustainability Councils) could be involved in this initiative (Göll, 2019). Globally, in Dubai, in 2018 at the World Government Summit, the Sustainable Development Goals Global Council was established as a global multilevel and multidimensional network of cooperation between governments, international organizations, NGOs, the world of science, and business. The head of the world council has been the Minister of State for International Cooperation of the UAE, Reem Al Hashimy (Lootah, 2019).

Based on the 2018 Eurostat report, the European Commission published in January 2019 the document 'Towards a sustainable Europe by 2030', which presents the achievements of the EU in meeting the goals of sustainable development. The European Council on 20th June 2019 approved an agenda for the EU for the next five years: 'A new strategic agenda 2019-2024'. One of the priorities is promoting European interests and values on the global stage in the area of sustainable development goals (Reflection Paper, 2019). As soft and civilian powers, the United Arab Emirates and the European Union decided to build strategic relations, including related to UN 2030 Agenda and Sustainable Development Goals. Analysing separate, but also almost overlapping temporarily and thematically initiatives of the UAE and the European Union, the author of this article would like to point out the need to combine common efforts. Certainly, joint projects combining efforts and ambitions contribute to faster and more complete implementation of SDGs.

\section{EMPIRICAL RESULTS AND DISCUSSION}

This empirical research and its results are the result of 10 years of direct observation, but also of the author's participation in many initiatives, both EU and UAE. The relations between the United Arab Emirates and the EU have been gradually deepening since 2010. This is due, inter alia, to new dynamics and new CFSP institutions resulting from the entry into force of the Treaty of Lisbon in December 2009 and the new US strategy announced in 2011, which underlined the transfer of US strategic interest from the Atlantic and the Middle East to the Pacific, East Asia (Clinton, 2011). This was of great importance for both the strategies of European countries and the Middle East. In addition to this new international situation, the UAE's foreign and security policy strategy of diversifying strategic alliances is also conducive to the development of UAE-EU relations. In addition, the UAE is diversifying its sources of income, moving away 
from oil production and focusing on the green economy and renewable energy sources. In these areas, the European Union has emerged as a valuable strategic partner. On June 14, 2010 in Luxembourg, the GCCEU Ministerial Council adopted the joint program of activities for the years 2010-2013 (Council of the European Union, 2010). A number of initiatives have been planned to implement this strategy. One of them is 'Establishment of European Union - GCC Network for clean energy'. At that time, a new dynamic of relations with Europe took place, both at the political and economic level. In addition, at the beginning of 2011, the so-called the Arab Spring, in which the EU wanted to be active, check the effectiveness of new institutions and show global ambitions. At that time, the UAE held the chairmanship of the GCC. Therefore, in April 2011, the EU-GCC Joint Council and Ministerial Meeting took place in Abu Dhabi, which was also attended by Catherine Ashton, EU High Representative for Foreign Affairs and Security Policy / Vice-President of the European Commission. During her visit she met with the UAE Foreign Minister Sheikh Abdullah bin Zayed Al Nahyan, and the Crown Prince of Abu Dhabi, Sheikh Mohammed bin Zayed bin Sultan Al Nahyan. During the meetings, she emphasized common challenges and shared interests (EU, 2011). In the same year, the EU engaged in the international forum to establish an international cooperation platform in the UAE to combat terrorism. In December 2012, the Hedayah Countering Violent Extremism Center was created in Abu Dhabi, of which the EU became a member of the board (European Commission, 2015). The following year, 2013, the EU-UAE parliamentary friendship group was established. On October 3, 2013 in Brussels, Sheikha Lubna Al Qassimi, UAE Minister for Development and International Cooperation called for a closer strategic partnership between the UAE and the EU (Awad, 2013). In the second half of the year, the EU opened its Delegation in Abu Dhabi, whose first EU ambassador, was Michail Stuparu. It was a recognition of the UAE as an important partner of the European Union, with which they share more and more common interests and global challenges. From March 2014, citizens of the 'new' EU began to be treated the same as citizens of the 'old union' in relation to visa requirements. In June 2014, the regional secretariat of the Centre for Chemical, Biological, Radiological and Nuclear Excellence (CBRN), funded by the European Instrument for Stability, was launched by the European Union in cooperation with the United Arab Emirates, in Abu Dhabi. This institution was established to ensure readiness to deal with chemical, biological, radiological and nuclear incidents in not only national but also regional areas. This project is part of a global security strategy in which the UAE has become an important partner for the EU (Malek, 2014). In May 2015, the agreement between the European Union and the United Arab Emirates on the short-stay visa waiver entered into force. This Agreement provides that Union citizens and UAE nationals may travel without a visa to the territory of the other Contracting Party for a maximum period of 90 days in any 180-day period (Council of the EU, 2015). It should be noted that under this agreement, visa-free travel to the EU applies only to the UAE, from the entire region of. So, this decision should be taken as an important emphasis on the importance of the UAE for the European Union. In addition, it should be noted that in 2015, a small UAE country took seventh place on the EU's global map of exports. However, for the UAE, the European Union has become the largest trading partner.

After adopting UN Agenda 2030 in 2015, the European Union and UAE began each meeting, and almost every element of cooperation, focused on SDG's. In April 2016, EU Commissioner for Research, Science and Innovation, Carlos Moedas met with the chairman of the Federal National Council (FNC), Amal Abdullah Al Qubaisi. The purpose of the meeting was primarily to deepen cooperation in the field of energy and scientific research. During the meeting, among others the UAE energy strategy was analysed, plans of the United Arab Emirates to extend the reuse of sea water to achieve about 40 percent savings in daily consumption. On the other hand, in the field of renewable energy, the plan discussed at a cost of USD 200 million, to create in the northern Emirate of Ras Al Khaimah the world's largest environmentally friendly desalination plant. Carlos Moedas emphasized that the UAE has become a role model in sustainable 
development and investment in renewable energy. In addition, the Commissioner emphasised the commitment of the UAE to the peaceful use of its nuclear energy and activity for the non-proliferation of nuclear weapons (WAM, 2016).

On April 25, 2016 in Brussels, the High Representative of the Union for Foreign Affairs and Security Policy / Vice-President of the Commission met with the President of the Federal National Council (FNC) Amal Al Qubaisi. With regard to SDG's, the UAE's achievements were recognised in the context of tolerance and in the fight against radicalism, strengthening women's role in social life. In addition, world peace and the Middle East were raised. In this context, views were exchanged on situations in Yemen, Syria and Iran (EEAS, 2016). The next Working Groups Consultation Workshop of the EU GCC Clean Energy Network II took place in Dubai next month, organised in cooperation with the European Union and the Dubai Supreme Council of Energy. The meeting emphasised primarily on renewable energy sources and the energy transformation for clean energy. In addition, the goal was to start work on developing a joint EU-UAE plan of cooperation in these fields, and to implement the assumptions of SDG's (Mouriadou, 2016). In January 2017, European Commission Vice President Jyrki Katainen, responsible for employment, growth, investment and competitiveness, took an official visit to the UAE. The purpose of the visit was to encourage partners from the UAE to even closer economic and investment cooperation with the EU. To this end, during talks, the Vice-President of the European Commission presented an investment plan for Europe (Stur, 2017). In May 2017, the Solar Rooftop Forum took place in Dubai, whose partner was the EU-GCC Clean Energy Technology Network. One of the goals was to speed up the implementation of Dubai's plans for the use of solar energy in the residential, commercial and industrial sectors. It is one of the elements of the strategy for achieving an ever-higher level of clean energy.

In January 2018, in order to deepen the political dialogue between the EU-UAE and develop strategic cooperation in important areas such as trade, innovation, research, education, transport, environment, health, consumer protection and multilateral cooperation, a cooperation agreement was signed between the European External Action Service and the UAE Ministry of Foreign Affairs and International Cooperation (EEAS, 2018). In order to implement the agreement, the EU took part in the Annual Investment Meeting in April of the same year in Dubai, the most important annual event on the economy, trade and investment. The EU representative, Ewa Synowiec, Chief Advisor to the European Commission and the General Directorate of Trade held numerous meetings in order to give even more dynamism to economic relations between the EU and the UAE, emphasising that there is great potential for the implementation of this vision (Esraa, 2018). Ewa Synowiec underlined the importance of UAE for trade with the EU, as by far the largest export market for the European Union in the GCC region, reaching the level of EUR 42 billion in 2017 (USD 51.65 billion). However, total trade in goods between the EU and the United Arab Emirates reached EUR 52.6 billion (USD 64.69 billion). The largest share in the European Union exports were transport machinery and equipment (over half), manufactured goods and chemicals. And the most important position in imports from the UAE to the EU market were mineral fuels, lubricants and other related materials, as well as manufactured goods (WAM, 2018).

Developing relations, Chairman of the United Arab Emirates Parliament Amal Al Qubaisi in January 2019 in Brussels met High Representative of the European Union for Foreign Affairs and Security Policy and Vice President of the European Commission, Federica Mogherini. The interlocutors emphasised the important role and significance of the UAE in the area of security and stability in the fight against terrorism as well as for the fulfilment of SDG's. As emphasised by Federica Mogherini, the UAE is a strategic ally for the EU. When discussing the situation of Yemen and humanitarian aid, Amal Al Qubaisi said that the United Arab Emirates in the period from April 2015 to December 2018 granted Yemen with humanitarian aid of USD 4.9 billion. Moreover, the total humanitarian aid granted in 2013 to 2017 is at the level of US \$32.01 billion. During her visit to Brussels, chairwomen of the United Arab Emirates Parliament met with 
representatives of the European Parliament and presented an exhibition on the global humanitarian and humanitarian activities of the UAE, entitled 'Humanitarian Aid for Stability'. The President of the European Parliament, Antonio Tajani, stressed the need for further intensified cooperation of the United Arab Emirates and the EU in the Middle East and North Africa in the fight against terrorism, illegal immigration and increased security. However, during the exhibition Emirates Red Crescent Deputy Secretary-General for Development and International Cooperation Fahad Abdelrahman Bin Sultan stressed that humanitarian and development assistance in the United Arab Emirates focused on meeting the needs of refugees and civil displaced persons in unstable areas such as Syria, Yemen, Somalia, Palestine, Afghanistan and Iraq. In addition, he also noted that the UAE for the fifth year in has the first place in the world in terms of the level of humanitarian and development assistance in relation to domestic GDP (Esraa \& Rasha, 2019).

During the exhibition, the distribution of UAE humanitarian aid was presented, which is as follows:

Table 1

The UAE humanitarian aid

\begin{tabular}{|l|c|c|}
\hline \multicolumn{1}{|c|}{ State } & Amount (USD) & Period \\
\hline Yemen & $4,92 \mathrm{mld}$ & $03.2015-12.2018$ \\
\hline Syria & $963,5 \mathrm{mln}$ & $2012-11.2018$ \\
\hline Iraq (Erbil) & $641,5 \mathrm{mln}$ & $2013-2017$ \\
\hline Palestine & $489 \mathrm{mln}$ & $2013-2018$ \\
\hline Afghanistan & $333,3 \mathrm{mln}$ & $2013-2017$ \\
\hline Somalia & $233,3 \mathrm{mln}$ & $2013-2017$ \\
\hline Libya & $174,6 \mathrm{mln}$ & $2013-2017$ \\
\hline
\end{tabular}

Source: https://dubaigazette.com/uae-ranked-worlds-top-aid-donor-in-2017-oecd/

In addition, a seminar entitled 'From Humanitarian Aid for Stability: UAE and EU Together', organized by the UAE Federal National Council (FNC) in cooperation with the EU-UAE Parliamentary Friendship Group, was held in Brussels at the European Parliament in January 2019. The conference highlighted the growing global challenges that require humanitarian commitment and meet SDG's. In addition, the UAE's commitment in this area was recognised as a global model with which the EU wants to develop cooperation to jointly implement UN Agenda 2030. In addition, Antonio López-Istúriz White, Secretary General of the European People's Party and Member of the European Parliament called for unification of EU efforts and the UAE for humanitarian aid, but also in the fight against terrorism, in the field of economy and investment. Director of the Red Cross Office in the EU, Denis Haveaux said during the meeting that the Red Cross and the Red Crescent are jointly implementing many projects, including for victims of forgotten crises. In contrast, the EU Commissioner for Humanitarian Aid and Crisis Management Christos Stylianides presented the UAE as a model in its commitment to meeting global challenges (Sheena, 2019).

In July 2019, a political dialogue based on the Cooperation Arrangement signed in January 2018, was officially initiated in Brussels, during which the first meeting took place, chaired by the Secretary-General of the European External Action Service, Helga Maria Schmid, and UAE Minister of State for Foreign Affairs, Dr. Anwar Gargash. More than ever before, the EU and UAE are interested in closer cooperation in political dialogue, non-proliferation and the fight against terrorism, trade, economic relations and antipiracy, as well as cooperation and humanitarian development. During the meeting, talks largely focused on the challenges related to the Middle East Peace Process, the situation in Syria, Yemen and Sudan as well as Libya, Iraq, Afghanistan, the Horn of Africa, the Sahel. In addition, the discussions concerned supporting 
each other in various projects. In this context, they discussed the Expo 2020 Dubai, for which SDG's are the key themes of the event. The talks showed the need to further deepen relations regarding strategic problems in the common interest. Therefore, it was decided to set up thematic Working Groups (Alfaham, 2019). Following the first meeting of the EU-UAE political dialogue, Sheikh Abdullah bin Zayed Al Nahyan, Minister for Foreign Affairs and International Cooperation, met in January 2020 in Brussels with Josep Borrell, High Representative of the European Union, EU Foreign Affairs and Security Policy and VicePresident of the Commission European Union. During the meeting, all the most important strategic topics related to the Middle East and issues of participation in Dubai Expo 2020 were discussed. The High Representative of the European Union for Foreign Affairs and Security Policy emphasised the achievements of the UAE in the SDG's areas. The interlocutors underlined the need to strengthen relationships (MOFAIC, 2020).

Developing and deepening cooperation between the European Union and the UAE and the entire GCC in the field of sustainable 'clean' energy and energy efficiency is crucial. It is beneficial for both partners. It should bring more effective implementation of political and economic interests, especially in the area of new technologies. In addition, enhanced, effective in implementing plans and strategies, cooperation should contribute to the implementation of the Paris Agreement on climate change concluded in December 2015 and a significant reduction of greenhouse gas emissions in the Gulf.

\section{CONCLUSION}

According to much research, by 2050 due to climate change and environmental degradation, hundreds of millions of people will leave their homes, which will cause far larger than recent, immigration waves into the EU. In global actions facing climate change, the countries of the Gulf Cooperation Council (GCC) are more and more involved. Some GCC governments, like the United Arab Emirates, play a very important role in these activities. Due to the emerging global political vacuum, the European Union and its partners, including the United Arab Emirates have great opportunities to enter the path of global leadership as civilian and soft powers in setting standards for UN 2030 implementation and future development paths for other countries and international entities. It is also important to stress the role and importance of Sustainable Development Goals for the EU Global Strategy for EU Foreign and Security Policy, which has been identified as a priority. The EU, especially as a civilian power, has a special role in promoting the SDGs for building a new stable global security structure based on the peaceful coexistence of states and cooperation in response to global challenges. Therefore, the European Union wants to secure the position of a credible global leader in the new security architecture must be a leading entity in the implementation of UN 2030. A great opportunity to strengthen the UAE soft power and accelerate commitment to Sustainable Development Goals will be the World Expo, which will be held in Dubai from October 2021 to March 2022, with one main topic of global sustainability cooperation. Certainly, Sustainable Development Goals, UN 2030 Agenda are the elements that create interdependence which allows maximizing the power of each party. Therefore, another value of this research paper and the author's contribution to the scientific discussion on the subject is one of the key issues for complex interdependence, the issue of domestic relations and foreign policies in the context of international interdependence, which shows the UAE's state case study and the example of the EU as the most integrated, the interdependence of organization in the world. 


\section{REFERENCES}

Abed, I., \& Hellyer, P. (2001). United Arab Emirates: A New Perspective. Trident Press Ltd, 165.

Alevizos, H. (2017). Renewable Sources of Energy: The Pan-Arab Prospect Energy and Environmental Policy Laboratory, in: Working Paper, 6 December 2017, University of Piraeus, 9. http://energypolicy.unipi.gr/wpcontent/uploads/2017/12/Unipi_WP6_Alevizos2017.pdf.

Aldroubi, M. (2018). UAE to take the international lead on soft power, The National, December 27. https://www.thenational.ae/world/gcc/uae-to-take-international-lead-on-soft-power-1.806868.

Alfaham, T. (2019). UAE, EEAS hold first Senior Officials' Meeting to launch the Cooperation Arrangement. WAM. https://www.wam.ae/en/details/1395302776990.

Ardemagni, E. (2019). The Geopolitics of Tolerance: Inside the UAE's Cultural Rush, 03 febbraio 2019, ISPI (Istituto per gli Studi di Politica Internazionale).

Alam, T., \& Luomi, M. (2018). Engaging Gulf Non-state and Subnational Actors in Implementing the Paris Agreement, Earth Matters Consulting, in: EDA Working Paper, May 2018, Emirates Diplomatic Academy, 28-29.

Al Hawi, F., Al Ketbi, H., Al Humairi, M., Thomas, L., \& Warner, R. (2018). Realizing a Smarter City through Smarter Human Capital, in: Policy Brief, No. 53, Mohammed Bin Rashid School of Government, December $2018,2$. https://www.mbrsg.ae/getattachment/a791e3f1-ffbc-4fb5-89dc-d783ecd1ded1/Realizing-a-Smarter-Citythrough-Smarter-Human-Cap

Al Suwaidi, A. (2017). The UAE Soft Power in the International Relations Context. International Journal of Social Science and Humanities Research, 5(4).

Awad, M. (2013).UAE boosts diplomatic presence in Europe. The National. Dubai. https://www.thenational.ae/uae/government/uae-boosts-diplomatic-presence-in-europe-1.292926

Ballard, J. (2017). Strategic Approaches The Potent smart-Power of the UAE, National Defense College, 01 February 2017. http://www.ndc.ac.ae/en/strategic-approaches-the-potentsmart-power-of-the-uae

Ballard, J. (2016). Strategic Issues: Coordinating National Power, National Defense College, 04 December 2016. http://www.ndc.ac.ae/en/strategic-issues-coordinating-national-power

Ballard, J. (2017). Strategic Issues: Sources of National Strength, 04 January 2017, National Defense College. http://www.ndc.ac.ae/en/strategic-issues-sources-of-national-strength

Brljavac, B., \& Conrad, M. (2011). A Global Civilian Power? The Future Role of the European Union in International Politics, Reykjavik, 99.

Burckhardt, C.W., (2004). Why is there a public debate about the idea of a 'Civilian Power Europe’?, EI Working Paper 2004 - 02, London School of Economics and Political Science, European Institute, p. 10.

Burton, G., \& Osman, E. (2018). Thinking about Sustainability and Sustainable Development with Public Private Partnerships, in: Sustainable Development, Session No. 11, January 2018, Mohammed Bin Rashid Al Maktoum Global Initiatives, Policy Council on PPPs, 4-5. https://www.mbrsg.ae/getattachment/f6801325-608c-41f8b990-feff44d29f95/Thinking-about-Sustainability-and-Sustainable-Deve

Clark, H. (2018). Time for Strong Partnerships for the SDGs, in: ED A Reflection, November 2018, Emirates Diplomatic Academy.

http://www.eda.ac.ae/docs/default-source/Publications/edareflection_sdgpartnerships_en_final.pdf?sfvrsn=2

Clinton, H. (2011). America's Pacific Century: The future of politics will be decided in Asia, not Afghanistan or Iraq, and the United States will be right at the Centre of action, Foreign Policy, November 2011.

Council of the EU. (2015). EU signs visa waiver agreement with the United Arab Emirates. Press release http:/ / data.consilium.europa.eu/doc/document/ST-7103-2015-INIT/en/pdf

Council of the European Union. (2010). 20th EU-GCC Joint Council and Ministerial Meeting, Joint Communique, Presse 197. Luxembourg, 14 June 2010.

Duchêne, F. (1972). Europe in World Peace, in: Europe Tomorrow: Sixteen Europeans Look Abead, ed. Mayne R., London

Duchene, F. (1973). The European Community and the Uncertainties of Interdependence. In Max Kohnstamm and Wolfgang Hager, eds, A Nation Writ Large? Foreign-Policy Problems before the European Community. London: Macmillan, 19.

EEAS (2016). Federica Mogherini, HR/VP meets with Dr. Amal Al Qubaisi, UAE Federal National Council Speaker in Brussels. Press releases: 160818_2. Brussels. https://eeas.europa.eu/headquarters/headquarters- 
homepage_is/8363/Federica $\% 20$ Mogherini, $\% 20 \mathrm{HR} / \mathrm{VP} \% 20$ meets $\% 20$ with $\% 20 \mathrm{Dr} . \% 20 \mathrm{Amal} \% 20 \mathrm{Al} \% 20 \mathrm{Qu}$ baisi, $\% 20$ UAE $\% 20$ Federal $\% 20$ National $\% 20$ Council $\% 20$ Speaker $\% 20$ in $\% 20$ Brussels

EEAS. (2018). EU and UAE sign a Cooperation Arrangement. Press releases: 180131_15. Bruxelles. https:/ / eeas.europa.eu/headquarters/headQuarters-

homepage_it/39170/EU\%20and\%20UAE\%20sign\%20a\%20Cooperation\%20Arrangement

Esraa, I. (2018). UAE's total trade with the European Union reached EUR 52 billion. WAM. http://wam.ae/en/details/1395302680408

Esraa, I., \& Rasha A. (2019). UAE a global model for promoting peace through bumanitarian role in Yemen, says EU President. WAM. http://wam.ae/en/details/1395302732327

EU. (2011). EU High Representative Catherine Ashton visits the Gulf, MEMO/11/250. Brussels, 17 April 2011. https://ec.europa.eu/commission/presscorner/detail/en/MEMO_11_250

European Commission. (2015). The Participation Of The European Union In Various Organisations For Cooperation To Prevent And Counter Terrorism. Joint Decision Of The European Commission And The High Representative Of The Union For Foreign Affairs And Security Policy. Join(2015) 32 Final. Brussels, 27.8.2015. https://eurlex.europa.eu/legal-content/EN/TXT/HTML/?uri=CELEX:52015JC0032\&from=EN

Erdağ, R. (2016). Towards European Security Integration: Boundaries of European Security and Defence Policy, Journal of European Integration 38(2), 211-217.

EU and UAE sign a Cooperation Arrangement, Bruxelles, 31/01/2018 - 18:31, UNIQUE ID: 180131 15. https:/ / eeas.europa.eu/delegations/fiji/39170/press-release-eu-and-uae-sign-cooperation-arrangement_nl

Europe 2020: A European strategy for smart, sustainable and inclusive growth, European Commission, Brussels, 3.3.2010 $\operatorname{Com}(2010) 2020$.

Everts, S. (2002). A Word of Advice from Europe: Soft Power Works. The National Interest, 1(6).

Excellence In Implementation: Executive Summary, Voluntary National Review, Un High Level Political Forum 2018, National Committee on Sustainable Development Goals, 16.

Gibbins, J. (2017). Power play: The United Arab Emirates' new approach to geopolitics, Journal of Middle Eastern Politics and Policy. Cambridge, MA: Harvard Kennedy School of Government. http://hksjmepp.com/united-arabemirates-geopolitics/

Gnesotto, N. (2001). Terrorism and European integration. Newsletter 35 ISS - Paris, 2001.

Government.ae Climate Action, (2018). https://www.government.ae/en/about-the-uae/leaving-no-onebehind/13climateaction (23.12.2018)

Governmentae, (2018). Efforts towards sustainability. https://government.ae/en/information-andservices/environment-and-energy/environmental-protection/efforts-towards-sustainability (01.11.2018)

Government.ae, (2018). Green Economy for Sustainable Development https://www.government.ae/en/about-theuae/economy/green-economy-for-sustainable-development (16 Oct 2018)

Government.ae, (2018). Dubai Clean Energy Strategy. https://government.ae/en/about-the-uae/strategies-initiativesand-awards/local-governments-strategies-and-plans/dubai-clean-energy-strategy (12.11.2018)

Government.ae, (2019). Gender Equality. https://www.government.ae/en/about-the-uae/leaving-no-onebehind/5genderequality (07.05.2019)

Griffiths S., (2018). Bilateral Energy Diplomacy in a Time of Energy Transition, in: EDA Insight, December 2018, Emirates Diplomatic Academy, 9-10. http://www.eda.ac.ae/docs/default-source/Publications/edainsight_fret-ii_bilateral-diplomacy_en.pdf?sfvrsn=2

Gulf News, (2017). UAE's Soft Power Strategy discussed, Gulf News, September 26, 2017. https://gulfnews.com/uae/government/uaes-soft-power-strategy-discussed-1.2096694

Goll, E., Uhl, A., \& Zwiers, J. (2019). Sustainable Development In The Mena Region, MENARA Future Notes No. 20 , March 2019, 5-7.

Günek, A. (2018). A New Type of Soft Power: Country Branding, International Journal of Cultural and Social Studies (IntJCSS), June 2018: Volume 4, Issue 1. https://dergipark.org.tr/download/article-file/525907

Hertog, S. (2017). A quest for significance: Gulf oil monarchies' international 'soft power' strategies and their local urban dimensions. LSE Kuwait Programme Paper Series (42). The London School of Economics and Political Science, London, UK. 
Hettne, B., \& Söderbaum, F. (2005). Civilian Power or Soft Imperialism? The EU as a Global Actor and The Role of Interregionalism, European Foreign Affairs Review, 17-18.

Hill, C. (1990). European foreign policy, power bloc, civilian model, or flop? In: The European of an International Actor. Western Europe's New Assertiveness, ed. Rummel R., Boulder 1990, 54.

Koutrakos, P. (2017). The European Union's Common Foreign and Security Policy After the Treaty of Lisbon, Stockholm: Swedish Institute for European Policy Studies, 2017.

Laursen, F. (2016). The EU's Common Foreign and Security Policy (CFSP) after the Lisbon Treaty: Supranational Revolution or Adherence to Intergovernmental Pattern?, F. Laursen (ed.) in The EU's Lisbon Treaty, 67-87, Routledge.

Lequesne, C. (2016). The European External Action Service: Can a New Institution Improve the Coherence of the EU Foreign Policy? in The EU's Foreign Policy, Routledge, 97-104.

Lonardo, L. (2017). 'The political question doctrine as applied to common foreign and security policy', European Foreign Affairs Review 22(4), 2017, 575.

Lootah, A.N. (2019). 'Excellence in Implementation': The UAE Model in Reaching the Global Agenda 2030, in: ED $A$ Reflection, May 2019, Emirates Diplomatic Academy.

Luomi, M. (2018). The Foreign Relations of Energy Transition -Framing the Issue for the UAE, in: EDA Insight, December 2018, The Foreign Relations of Energy Transitions Series, 9.

Madakam, S., \& Ramaswamy, R. (2016). Sustainable Smart City: Masdar (UAE) (A City: Ecologically Balanced), in: Indian Journal of Science and Technology, Vol 9(6), National Institute of Industrial Engineering (NITIE), February 2016, p. 5 and 6.

Malek, C. (2014). EU sets up international centre in Abu Dhabi. The National. Dubai. https://www.thenational.ae/uae/government/eu-sets-up-international-centre-in-abu-dhabi-1.255060

Manners, I. (2002). Normative Power Europe: A Contradiction in Terms? Rutherford College University of Kent, Canterbury, 26.

Maull, H. (1990). Germany and Japan: The New Civilian Powers, Foreign Affairs, vol. 69, no. 5, 1990, 92-3.

Mills, R. (2017). Global Governance of Carbon Capture and Storage: Role for the GCC?, in: EDA Insight, December 2017, Emirates Diplomatic Academy, 8.

Ministry of Climate Change and Environment, 30 May 2019.

MOCAF. (2017). Mohammad Bin Rashid launches UAE Soft Power Council. https://www.mocaf.gov.ae/en/media/news/mohammad-bin-rashid-launches-uae-soft-power-council

MOEI, (2019). Vice President unveils UAE energy strategy for the next three decades. https://www.moei.gov.ae/en/mediacentre/news/10/1/2017/ (07.05.2019)

MOFAIC. (2020). H.H. Sheikh Abdullah bin Zayed meets EU High Representative. News. https://www.mofaic.gov.ae/en/mediahub/news/2020/1/23/23-01-2020-uae-european-union

Montéville, M., \& Kettunen, M. (2019). Assessing and accelerating the EU progress on Sustainable Development Goals (SDGs) in 2019, a briefing to inform the UN High Level Political Forum (HLPF) and the SDG Summit in New York (9 - 18 July and 24 - 25 September 2019), IEEP 2019, 6-7, 11.

Mouriadou, G. (2016). EU-GCC Clean Energy Technology Network. Working Groups Consultation Workshop. Dubai. http://www.eugcc-cleanergy.net/wg-workshop2016\%2CDubai

Mulholland, E. (2017). The Role of European Parliaments in the Implementation of the 2030 Agenda and the SDGs, ESDN Quarterly Report 45, July 2017, ESDN Office, Vienna.

Nye, J. (2004). Soft Power: The Means to Success in World Politics, Foreign Affairs, May/June 2004 Issue.

Özer, Y. (2012). The European Union As A Civilian Power: The Case Of The Eu's Trade Policy, Marmara Journal of European Studies, Volume 20, No: 2, 85.

Pehlivantürk, B., \& Demirtas, B. (2018). Civilian Powers and Contemporary Global Challenges, Perceptions, Spring 2018, Volume XXIII, Number 1, 4. https://www.moccae.gov.ae/assets/30e58e2e/national-climate-change-planfor-the-united-arab-emirates-2017-2050.aspx (17.05.2019)

Prodi, R. (2000). 2000-2005 Shaping the New Europe. Speech to the European Parliament. Speech/00/41. Strasbourg, 15 Feb.

Reflection Paper: Towards A Sustainable Europe By 2030, European Commission 2019, 7-9. 
Riddervold, M. (2016). '(Not) in the hands of the member states: How the European Commission influences EU security and defence policies', JCMS: Journal of Common Market Studies, Wiley Blackwell 54(2), 353-369.

Riddervold, M., \& Rosén, G. (2016). 'Trick and treat: How the Commission and the European Parliament exert influence in EU foreign and security policies', Journal of European Integration 38(6), 687-702.

Saberi, D. (2018). Paris Cody Morris, Marochi Belisa, Soft power and place branding in the United Arab Emirates: examples of the tourism and film industries, International Journal of Diplomacy and Economy, Volume 4, Issue 1, 2018.

Salem, F. (2016). A Smart City for Public V alue. Digital Transformation through Agile Governance - The case of "Smart Dubai", Dubai: Governance and Innovation Program, Mohammed Bin Rashid School of Government, World Government Summit, February 2016, 5, 44. https://www.mbrsg.ae/getattachment/6f151e2b-0c5f-407f-ae35ab70934c2d58/A-Smart-City-for-Public-Value (07.07.2019)

Sheena, A. (2019). UAE ranked world's top aid donor in 2017: OECD. Dubai Gazette. Dubai. https://dubaigazette.com/uae-ranked-worlds-top-aid-donor-in-2017-oecd/

Smith, K.E., (2005). Still 'civilian power EU? European Foreign Policy Unit Working Paper 2005/1, London School of Economics, 17.

Smith, K.E., (2005). Beyond The Civilian Power EU Debate, Politique Européenne, 2005/3 N 17, 64.

Stephens, M., El-Sholkamy, Moonesar I.A., \& Awamleh R. (2019). Future Governments, Academy of International Business, Mohammed Bin Rashid School of Government, 73.

Stur, B. (2017). Jyrki Katainen: 'There is untapped trade potential between GCC and Europe'. NewEurope. https://www.neweurope.eu/article/jyrki-katainen-untapped-trade-potential-gcc-europe/

Sustainable Development Report (2019). Transformations to achieve the SDG, Bertelsmann Stiftung and Sustainable Development Solutions Network.

https://s3.amazonaws.com/sustainabledevelopment.report/2019/2019_sustainable_development_report.pdf

SWFI. (2019). Top 81 Largest Sovereign Wealth Fund Rankings by Total Assets. https://www.swfinstitute.org/fundrankings/sovereign-wealth-fund

Telò, M., \& Ponjaert F. (2016). The EU's Foreign Policy: What Kind of Power and Diplomatic Action? London, New York, 62.

Tulmets, E. (2008). The European Union: A “Soft Power” With Civilian Means?, Kultura i Polityka, 2008/2-3, 61.

UAECABINTET. (2019). The National Strategy for Innovation. https://uaecabinet.ae/en/the-national-strategy-forinnovation (08.05.2019)

Urpelainen, J. (2018). International Cooperation on 7 SDG on Affordable and Clean Energy for All, in: EDA Insight, December 2018, Emirates Diplomatic Academy, 4. http://www.eda.ac.ae/docs/defaultsource/Publications/eda-insight_fret-iv_cooperation-on-sdg7_en.pdf?sfvrsn=2

WAM. (2017). Mohammed bin Rashid launches UAE Soft Power Council. http://wam.ae/en/details/1395302611062

Water in the 2030 Agenda for Sustainable Development: How Can Europe Act?, United Nations and Cultural Organization, 2019, 21.

Woodward, R., (2018). The UAE - Soft Superpower In The Making? TRENDS Research \& Advisory, May 30, 2018. http:/ / trendsinstitution.org/the-uae-soft-superpower-in-the-making/

UAE, EEAS hold first Senior Officials' Meeting to launch the Cooperation Arrangement, WAM/Tariq Alfaham, 2019.

UAE Space Agency. (2019). Hope Probe. https://www.space.gov.ae/Page/20121/20167/Hope-Probe

WAM. (2016). EU praises UAE's drive for renewable energy. https://www.emirates247.com/news/emirates/eu-praisesuae-s-drive-for-renewable-energy-2016-04-29-1.628755

WAM. (2018). UAE-EU trade hits \$65bn. Dubai. http://emirates-business.ae/uae-eu-trade-hits-65bn/

Zielonka, J. (2006). Explaining Euro-Paralysis: Why Europe is Unable to Act in International Politics. Macmillan Press, 227. 